\title{
Clinical and radiographic evaluation of the Periodontium with biologic width invasion
}

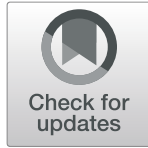

Bruna Almeida Silva Carvalho, César Augusto Barroso Duarte, Jaciara Fagundes Silva, Walter Winícius da Silva Batista, Dhelfeson Willya Douglas-de-Oliveira*, Evandro Silveira de Oliveira, Luana de Goés Soares, Endi Lanza Galvão, Gabriela Rocha-Gomes, José Cristiano Ramos Glória, Patrícia Furtado Gonçalves and Olga Dumont Flecha

\begin{abstract}
Background: The biologic width is defined as the coronal dimension to the alveolar bone that is occupied by healthy gingival tissue. The objective of the present study was to correlate radiographic findings of biologic width invasion with the periodontium status.

Methods: It were included 14 patients with restored teeth with biological width invasion, on the proximal sites, observed clinically and radiographically. 122 proximal sites were evaluated, 61 in the test group (biological width invasion) and 61 in the control group (adequate biological width). Smokers and patients presenting periodontal disease or restorations with contact in eccentric movements, horizontal over-contour or secondary caries were excluded from the sample. The invasion of the biologic width was diagnosed when the distance from the gingival margin of restoration to the bony crest was less than $3 \mathrm{~mm}$. Intrabony defect and bone crest level, as well as, their vertical and horizontal components were radiographically evaluated when present. Plaque index, bleeding on probing, probing depth, gingival recession height, keratinized gingival height and thickness, and clinical attachment level were clinically evaluated. Data were subjected to Spearman's Correlation and Wilcoxon's test.
\end{abstract}

Result: The most prevalent tooth with biological width invasion was the first molar. There was a statistically significant correlation between the bone crest $(p<0.001)$, vertical $(p<0.001)$ and horizontal $(p=0.001)$ components. In the test group, there was a statistically significant correlation between bleeding on probing $(p<0.001 ; r=0.618)$ and width of gingival recession ( $p=0.030 ; r=-0.602)$ with the intraosseous component; and between keratinized gingival height and bone level $(p=0.037 ; r=-0.267)$. In the control group, there was a correlation between plaque index $(p=0.027 ; r=-0.283)$ with bone level and correlation between keratinized gingival thickness and bone level $(p=0.034 ; r=-0.273)$ and intrabony component $(p=0.042 ; r=0.226)$.

Conclusion: A statistically significant relationship was found between bleeding on probing and gingival recession in patients who presented intrabony defects due to the invasion of biological width, which may be also related to the thickness of the keratinized gingiva.

Keywords: Biologic width, Periodontal health, Gingival inflammation, Bone loss, Interproximal radiography

* Correspondence: dhelfeson@hotmail.com

Department of Dentistry, Federal University of Jequitinhonha and Mucuri

Valleys, Rua da Glória, n’ 187. Centro, Diamantina, MG 39100-000, Brazil

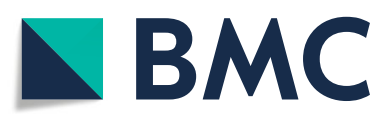

(c) The Author(s). 2020 Open Access This article is licensed under a Creative Commons Attribution 4.0 International License, which permits use, sharing, adaptation, distribution and reproduction in any medium or format, as long as you give appropriate credit to the original author(s) and the source, provide a link to the Creative Commons licence, and indicate if changes were made. The images or other third party material in this article are included in the article's Creative Commons licence, unless indicated otherwise in a credit line to the material. If material is not included in the article's Creative Commons licence and your intended use is not permitted by statutory regulation or exceeds the permitted use, you will need to obtain permission directly from the copyright holder. To view a copy of this licence, visit http://creativecommons.org/licenses/by/4.0/ The Creative Commons Public Domain Dedication waiver (http://creativecommons.org/publicdomain/zero/1.0/) applies to the data made available in this article, unless otherwise stated in a credit line to the data. 


\section{Background}

The supracrestal gingival tissue, also known as the biologic width is defined as the dimension that the healthy gingival tissue occupies coronally to the alveolar bone, involving the sum of the junctional epithelium and the connective insertion dimensions [1-3]. The average vertical dimensions of the biological width are known thanks to the study of Gargiulo et al. (1961) [4], however, nowadays, it is known that these measurements are not constant, being dependent on the location/inclination of the tooth in the socket $[5,6]$, varying between teeth [7], their sites [8] and gingival biotypes [9]. In general, its length is $3 \mathrm{~mm}$ from the bone crest to the cement-enamel junction in healthy teeth or until the end of the preparation or the margin of restoration in restored teeth [10].

The existence of the biologic width is fundamental for adhesion of the junctional epithelium and insertion of the connective fibers to the dental structure, besides functioning as a barrier against microbial entry in the periodontium. Therefore, the biologic width should be respected during restorable procedures in order to preserve periodontal health $[11,12]$.

Biologic width invasion may cause injuries to periodontal tissues, as a means of maintaining its physiological dimensions, resulting in chronic inflammation of the soft tissues around the restoration, bleeding on probing, gingival hyperplasia, gingival recession, periodontal pocket, with loss of clinical insertion and progressive alveolar bone loss, in addition to difficulties in adapting restorations $[13,14]$.

When a patient is evaluated with a periodontal probe and feels discomfort in the gums, close to a restoration, it may suggest that the margin violated the biologic width. The determination of the dimension of supracrestral gingival tissues through transulcular periodontal probing, as described by Jardini and Pustiglione [7], has been shown to be an important auxiliary method in the diagnosis of biological width violation [15]. The interproximal radiography, in turn, can identify these violations and is considered the ideal technique for a more accurate assessment of the proximal sites, in addition to being a non-invasive method $[14,16]$.

There is a gap in the literature about radiographic and clinical comparison in cases of biologic width invasion. An adequate understanding of the relationship between clinical and radiographic findings is necessary for a better diagnosed and treatment. The aim of this study was to correlate radiographic findings with the clinical conditions of periodontium in sites presenting biologic width invasion, in cases of both direct and indirect restorations.

\section{Methods}

This cross-sectional study was approved by the $\mathrm{Re}$ search Ethics Committee of the Federal University of Jequitinhonha and Mucuri Valleys (UFVJM), by protocol 026/12 and conducted according to the Declaration of Helsinki, 1975, revised in 2013. Written informed consent was obtained from all participants prior the study begins.

\section{Patient selection}

Patients who attended at the clinics of the Department of Dentistry UFVJM were invited to participate in this research until complete the sample. They were clarified about the objective, risks and benefits of participating in the research.

The sample size was determined with the following parameters: significance level 95\%, power of $80 \%$, minimum difference to be detected between the groups of $0.1 \mathrm{~mm}$, and the standard deviation of probing depth $(0.18 \mathrm{~mm})$ was obtained in a previous study [17]. It were added $20 \%$ to prevent losses. The calculations have determined that 61 teeth sites with invasion of biologic width would be sufficient to carry out the study.

\section{Eligibility criteria}

The study included patients over 18 years of age, with good general health, with no distinction of gender, ethnicity or socioeconomic status. It were included restored teeth with biologic width invasion, on the mesial or distal sites, which was radiographically observed. It was considered as biologic width invasion when the distance between the restoration gingival margin and the alveolar bone crest was less than $3 \mathrm{~mm}$ [18].

Patients presenting periodontal disease, smokers or who had restorations with contact in eccentric movements, horizontal overcontour or secondary caries were excluded from the sample.

\section{Radiographic evaluation}

The radiographic parameters evaluated, in the test (biological width invasion) and control groups (adequate biological width), when there was intrabony defect were: (1) bone defect level (BDL), which is the distance between the restoration margin and the most apical portion of the defect where the space of the periodontal ligament presented normal width; (2) Bone crest level (BCL), measured between the margin of restoration and the projection of the most prominent portion of the alveolar bone crest on the root surface; (3) Vertical component (VC), defined by subtraction BDL - BCL; and, (4) horizontal component (HC), distance from bone crest to root surface (Fig. 1). 


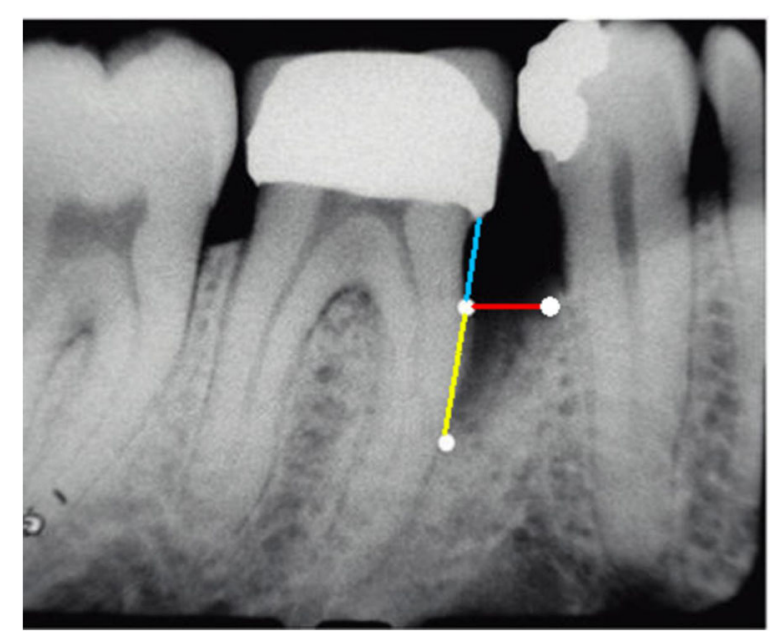

Fig. 1 (Adapted from Parashis et al., 2012). Radiographic parameters evaluated in intrabony defect. Blue: $B C L$; yellow: $V C$; red: $H C$; blue+yellow: $\mathrm{BDL}$

The radiographs analyzed were those that were already present in the patient records who were attended at the UFVIM dental clinic.

These measurements were taken with a dry-tip compass and transformed in millimeters with the aid of a millimeter ruler, for greater accuracy and reliability, being obtained by a second duly calibrated researcher.

The sites with biological width invasion were considered test group. As control group, it were used sites of the analogous or antagonistic tooth to the one that presented biologic width invasion.

\section{Clinical evaluation}

The clinical parameters evaluated, in the test and control groups, were: plaque index (PI) and bleeding on probing (BOP), both taken in percentage in relation to total number of sites, considering as positive the sites with visible plaque and with bleeding until $15 \mathrm{~s}$ after probing. The probing depth (PD) was determined by the distance from the gingival margin to the base of the gingival sulcus, performed with a computerized periodontal probe (Florida Probe). The gingival recession height (GRH) consists of the distance from the cement-enamel junction to the most apical extension of the gingival margin; gingival recession width (GRW), given by the distance from the right gingival margin to the left gingival margin at cement-enamel junction. Keratinized gingiva height $(\mathrm{KGH})$, measured as the distance from the gingival margin to the mucogingival line. Clinical attachment loss (CAL) given by the sum of PD and GRH. The keratinized gingiva thickness (KGT) was measured by perforation of the gingival tissue with a thin digital endodontic spacer and a rubber stop in the half of the KGH under topical anesthesia. The GRH, GRW and KGH were taken with manual periodontal probe and measured in millimeters. The clinical evaluation was performed by four examiners (BASC, CABD, JFS and WWSB) previously calibrated, the inter-examiner ICC ranged from 0.799 to 0.890 and the intra-examiner ICC ranged from 0.842 to 0.903 .

\section{Statistical analysis}

Statistical analyses were performed using the SPSS ${ }^{\circ}$ (Statistical Package for the Social Sciences Inc.), version 22. Descriptive analysis of the data provided frequencies, means and standard deviations. Data normality was assessed by the Shapiro-Wilk test. The Spearman correlation and Wilcoxon test were used to verify, respectively, the correlation and the association between the clinical and radiographic parameters. The confidence interval of $95 \%$ was used, and the significance level adopted was 5\%.

\section{Results}

The sample consisted of 13 women (93\%) and 1 man (7\%). The tooth that presented most biologic width invasion was the first molar, in both groups. It were evaluated 122 sites, being 30 mesial (49\%) and 31 distal (51\%) sites in test group, and 29 mesial (47.5\%) and 32 distal $(52.5 \%)$ sites in the control group (Table 1$)$. Gingival recession was observed in 18 teeth in test group and in 5 teeth in control group.

Table 2 shows the descriptive statistics for test and control groups. A statistically significant difference was observed between bone crest level $(p<0.001)$, bone defect level $(p=0,005)$, vertical $(p<0.001)$ and horizontal components $(p=0.001)$.

Table 1 Prevalence of biologic width invasion, according to teeth, to dental site and to the group

\begin{tabular}{llllll}
\hline Parameter & \multicolumn{2}{l}{ Test group } & & \multicolumn{2}{l}{ Control group } \\
\cline { 2 - 3 } & $\mathrm{n}$ & $\%$ & & $\mathrm{n}$ & $\%$ \\
\hline Tooth & 19 & 31.1 & & 18 & 29.5 \\
First Molar & 8 & 13.1 & & 11 & 18.0 \\
Second Molar & 11 & 18.0 & & 10 & 16.4 \\
First Pre-molar & 18 & 29.5 & & 16 & 26.2 \\
Second Pre-molar & 3 & 4.9 & & 4 & 6.6 \\
Canine & 2 & 3.3 & & 2 & 3.3 \\
Incisor & & & & \\
Site & 30 & 49.2 & & 29 & 47.5 \\
$\quad$ Mesial & 31 & 50.8 & & 32 & 52.5 \\
Distal & & &
\end{tabular}


Table 2 Average of the parameters related to the sites probed

\begin{tabular}{llllllll}
\hline & \multicolumn{2}{l}{ Test group } & & \multicolumn{3}{c}{ Control group } \\
Parameters related to the sites probed & Mean & SD & & Mean & SD & p-value \\
\hline Probing depth & 2.5 & 1.4 & 2.1 & 1.1 & 0.080 \\
Clinical attachment level & 2.7 & 1.4 & 2.3 & 1.3 & 0.095 \\
Height of gingival recession & 2.3 & 1.0 & 2.3 & 0.6 & 0.655 \\
Width of gingival recession & 4.0 & 1.6 & 2.7 & 1.3 & 0.180 \\
Keratinized gingiva height & 3.2 & 1.7 & 2.7 & 0.6 & 0.089 \\
Keratinized gingiva thickness & 1.4 & 0.4 & 1.4 & 0.6 & 0.691 \\
Level of bone defect & 0.9 & 1.3 & 0.2 & 0.9 & $\mathbf{0 . 0 0 5}$ \\
Bone crest level & 1.4 & 0.6 & 2.4 & 1.2 & $<\mathbf{0 . 0 0 1}$ \\
Intrabony component & 0.6 & 0.7 & 0.1 & 0.2 & $<\mathbf{0 . 0 0 1}$ \\
Horizontal component & 0.3 & 0.5 & 0.1 & 0.2 & $\mathbf{0 . 0 0 1}$
\end{tabular}

Values in bold showing statistically significant difference $(p<0.05)$.

The correlation between the clinical and radiographic parameters of the test group is observed in Table 3. In test group, it was observed a statistically significant correlation between BOP with the intraosseous component $(p<0.001) \quad(r=0.618)$, and GRW with the intraosseous component $(p=0.030)$ $(r=-0.602)$; and, between the KGH and the bone level $(p=0.037)(r=-0.267)$. In the control group, the correlation occurred between PI and BCL $(p=$ $0.027)(r=-0.283)$; and between KGT and BCL $(p=$ $0.034)(r=-0.273)$ and also of the intraosseous component $(p=0.042)(r=0.226)$, (Table 4$)$.

\section{Discussion}

Periodontal health is a basic requirement for both the longevity of restoration and the aesthetics, as well as, function and maintenance of dentition. However, dental restorations presenting width invasion are a frequently problem in clinical practice and are capable of inducing gingival inflammation, loss of connective tissue and unpredictable bone loss [19, 20]. Also, the invasion of the biologic width may cause periodontal pocket which does not imply the diagnosis of periodontal disease.

It was observed that the first molar, in the test and control groups, showed greater invasion of biological space. According to Vacek et al. [5], there are variations in the dimensions of the supracrestal gingival tissue between teeth, as well as in their sites, with the average molar measurements being greater than in the other groups of teeth.

The gingival recession and inflammation were clinically observed in this study, in addition to the correlation between the presence of width invasion and the decrease in the level of the bone crest observed radiographically, these findings similar to those reported by Douglas-deOliveira et al. [17].

The relationship between width invasion and bleeding on probing found in the literature and in the present study can be explained by the fact that the placement of restorative margins within the width space often leads to gingival inflammation, loss of clinical attachment and bone loss. This is probably due to the destructive inflammatory response of the microbial located deeper into the gingival sulcus. These alterations were justified by studies that evaluated the histological and clinical response of periodontal tissues to the position of the restoration margins within the biologic width [21, 22].

In the present study, the negative correlation between keratinized tissue height and bone level was observed in the test group, which means that the higher the keratinized tissue, the lower the level of bone defect. In fact, according to Stetler and Bissada [23], teeth with subgingival restorations and narrow keratinized gingiva have worse gingival inflammation compared to a wide range of keratinized tissue.

A negative correlation was found between plaque index and bone crest level in teeth with biologic width invasion in the control group. This can happen due to

Table 3 Correlation of clinical and radiographic findings for test group

\begin{tabular}{|c|c|c|c|c|c|c|c|c|}
\hline \multirow[t]{3}{*}{ Clinical parameters } & \multicolumn{8}{|c|}{ Radiographic parameters } \\
\hline & \multicolumn{2}{|c|}{ Level of bone defect } & \multicolumn{2}{|c|}{ Bone crest level } & \multicolumn{2}{|c|}{ Intrabony component } & \multicolumn{2}{|c|}{ Horizontal component } \\
\hline & $r_{5}$ & $p$ & $r_{s}$ & $\mathrm{p}$ & $r_{5}$ & $p$ & $r_{s}$ & $p$ \\
\hline Plaque index & 0.025 & 0.850 & 0.184 & 0.156 & 0.032 & 0.845 & 0.062 & 0.635 \\
\hline Bleeding on probing & -0.013 & 0.919 & -0.012 & 0.929 & 0.618 & $<0.001$ & 0.001 & 0.991 \\
\hline Probing depth & -0.010 & 0.940 & -0.035 & 0.788 & -0.037 & 0.821 & 0.033 & 0.802 \\
\hline Clinical attachment level & 0.131 & 0.315 & -0.084 & 0.519 & 0.294 & 0.069 & 0.128 & 0.325 \\
\hline Height of gingival recession & 0.271 & 0.277 & -0.104 & 0.682 & 0.355 & 0.234 & 0.420 & 0.083 \\
\hline Width of gingival revession & -0.127 & 0.616 & 0.292 & 0.240 & -0.602 & 0.030 & -0.266 & 0.287 \\
\hline Keratinized gingiva height & -0.267 & 0.037 & -0.069 & 0.595 & 0.034 & 0.840 & -0.266 & 0.080 \\
\hline Keratinized gingiva thickness & -0.072 & 0.580 & 0.101 & 0.436 & -0.172 & 0.294 & -0.072 & 0.580 \\
\hline
\end{tabular}

Values in bold showing statistically significant difference $(p<0.05)$. 
Table 4 Correlation of clinical and radiographic findings for control group

\begin{tabular}{|c|c|c|c|c|c|c|c|c|}
\hline \multirow[t]{3}{*}{ Clinical parameters } & \multicolumn{8}{|c|}{ Radiographic parameters } \\
\hline & \multicolumn{2}{|c|}{ Level of bone defect } & \multicolumn{2}{|c|}{ Bone crest level } & \multicolumn{2}{|c|}{ Intrabony component } & \multicolumn{2}{|c|}{ Horizontal component } \\
\hline & $r_{s}$ & $p$ & $r_{s}$ & $\mathrm{p}$ & $r_{s}$ & $p$ & $r_{s}$ & $p$ \\
\hline Plaque index & 0.166 & 0.201 & -0.283 & 0.027 & 0.156 & 0.231 & 0.231 & 0.073 \\
\hline Bleeding on probing & -0.122 & 0.348 & -0.063 & 0.629 & -0.131 & 0.314 & -0.014 & 0.915 \\
\hline Probing depth & -0.107 & 0.411 & 0.222 & 0.086 & -0.123 & 0.343 & 0.100 & 0.444 \\
\hline Clinical attachment level & -0.126 & 0.333 & 0.233 & 0.071 & -0.141 & 0.277 & 0,075 & 0.564 \\
\hline Keratinized gingiva height & -0.065 & 0.620 & 0.088 & 0.498 & -0.080 & 0.541 & 0.101 & 0.438 \\
\hline Keratinized gingiva thickness & 0.247 & 0.055 & -0.273 & 0.034 & 0.262 & 0.042 & 0.052 & 0.688 \\
\hline
\end{tabular}

The height and width of gingival recession did not run in this correlation due the low sample. Values in bold showing statistically significant difference $(p<0.05)$.

the biofilm retention in the rough surface areas of restoration that was brought into the gingival sulcus, where the patient is unable to properly cleaning his/her tooth, aggravating biofilm accumulation [24]. Consequently, this condition could lead to progressive gingival inflammation followed by periodontal destruction with greater pocket depth, attachment loss and gingival recession, increasing vertical bone resorption and increasing the horizontal component [17].

A negative correlation was also found between the thickness of the keratinized gingiva and the level of the bone crest in the control group. This result is in agreement with studies that evaluated gingival phenotype [9] in which a greater distance from the supracrestal gingival tissue was found in thin phenotype compared to the thick phenotype.

Thus the use of radiographic data is important to diagnose the biologic width invasion. Interproximal radiographs are the most used one for this purpose, since it presents less distortion than the other techniques [25]. In addition to this technique, a recent study [26] has shown an innovative parallel-profile radiography technique for gauging the dimensions of biological space on the labial sites of anterior teeth.

In a patient with preserved biologic width, the measure up to the bone crest has an average of $3 \mathrm{~mm}$ [12]. Furthermore, in the comparison between clinical and radiographic parameters in patients with invasion of the biologic width, association was observed between bleeding on probing, gingival recession and bone defects. This association was not found in the teeth of the control group, confirming the deleterious aspect of overlap restorations. These findings corroborate the concept that apically placed restorations within the supracrestal connective tissues may be harmful to periodontal health $[27,28]$.

\section{Conclusion}

It was concluded that the restorations with biologic width invasion were harmful to periodontal health, showed a statistically significant relationship between the bleeding on probing and gingival recession in those patients who had intrabony defect.

According to the results of the present study, it is suggested that the clinician should consider the gingival phenotype, as well as, bone morphotype, when performing restorative procedures in areas near the gingival sulcus.

To try to minimize these damages, dentists should respect the measurements of the biologic width in direct and indirect subgingival restorations, since the health of the periodontium depends on the non-violation of this anatomic site.

\section{Abbreviations \\ BCL: Bone Crest Level; BDL: Bone Defect Level; BOP: Bleeding On Probing; CAL: Clinical Attachment Loss; GRH: Gingival Recession Height; GRW: Gingival Recession Width; HC: Horizontal Component; KGH: Keratinized Gingiva Height; KGT: Keratinized Gingiva Thickness; PD: Probing Depth; PI: Plaque Index; VC: Vertical Component}

\section{Acknowledgments}

Not applicable.

\section{Authors' contributions}

BAS participated in the writing of the text. CABD participated in the writing of the text. JFS participated in the writing of the text. WWSB participated in the writing of the text. DWDO participated in data analysis, review of results and final manuscript. ESO participated in the writing of the text. LGS participated in the writing of the text. ELG participated in data analysis review and of results. GRG participated in the writing and final revision of the article. JCRG participated in data analysis review and of results. PFG participated in the writing of the English text, revision and final approval of the manuscript. ODF participated in the writing of the text and was responsible for the revision and final approval of the manuscript. The author(s) read and approved the final manuscript.

\section{Funding}

The study was self-supported by the authors.

\section{Availability of data and materials}

The datasets used and/or analysed during the current study are available from the corresponding author on reasonable request.

\section{Ethics approval and consent to participate}

This cross-sectional study was approved by the Research Ethics Committee of the Federal University of Jequitinhonha and Mucuri Valleys (UFVJM), by protocol 026/12 and conducted according to the Declaration of Helsinki, 1975, revised in 2013. Written informed consent was obtained from all participants prior the study begins. 


\section{Consent for publication}

Not applicable.

\section{Competing interests}

The authors declare that they have no competing interests.

Received: 20 January 2020 Accepted: 1 April 2020

Published online: 16 April 2020

\section{References}

1. Galgali SR, Gontiya G. Evaluation of an innovative radiographic techniqueparallel profile radiography- to determine the dimensions of thedentogingival unit. Indian J Dent Res. 2011;22:237-41.

2. Parashar A, Zingade A, Sanikop S, Gupta S, Parasher S. Biological width: the silent zone. Int Dental J Students Res. 2015:2:11-5.

3. Schmidt JC, Sahrmann P, Weiger R, Schmidlin PR, Walter C. Biologic width dimensions-a systematic review. J Clin Periodontol. 2013;40(5):493-504.

4. Gargiulo A, Wentz F, Orban B. Dimensions and relations of the dentogingival junction in humans. J Periodontol. 1961;32:261-7.

5. Vacek JS, Gher ME, Assad DA, Richardson AC, Giambarresi LI. The dimensions of the human dentogingival junction. Int J Periodontics Restorative Dent. 1994;14(2):154-65.

6. Tristao GC, Barboza CA Jr, Rodrigues DM, Barboza EP. Supracrestal gingival tissue measurement in normal periodontium: a human histometric study. Int J Periodontics Restorative Dent. 2014;34(1):97-102.

7. Jardini MAN, Pustiglioni FE. Estudo biometrico do espaco biologico em humanos por meio da sondagem transulcular. Rev. Pos Grad. 2000;7(4):295302.

8. Kois JC. Altering gingival levels: The restorative connection, Part I: Biologic variables. J. Esthet Dent. 1994;6:3-9.

9. Cook DR, Mealey BL, Verrett RG, Mills MP, Noujeim ME, Lasho DJ, Cronin RJ Jr. Relationship between clinical periodontal biotype and labial plate thickness: an in vivo study. Int J Periodontics Restorative Dent. 2011;31(4): 345-54.

10. Oh SL. Biologic width and crown lengthening: case reports and review. Gen Dent. 2010;58(5):200-5

11. Rosenberg ES, Cho SC, Garber DA. Crown lengthening revisited. Compend Contin Educ Dent. 1999;20:527

12. Nugala B, Kumar SB, Sahitya S, Krishna PM. Biologic width and its importance in periodontal and restorative dentistry. J Conservative Dent. 2012;15(1):12-7

13. Felippe LA, Monteiro Júnior S, Vieira LC, Araujo E. Reestablishing biologic width with forced eruption. Quintessence. 2003;34:733-8.

14. Shobha KS. Mahantesha, Seshan H, Mani R, Kranti K. Clinical evaluation of the biologic width following surgical crown lengthening procedure: $\mathrm{A}$ prospective study. J Indian SocPeriodontol. 2010;14:160-7.

15. Perez JR, Smukler H, Nunn ME. Clinical evaluation of the supraosseous gingivae before and after crown lengthening. J Periodontol. 2007;78(6): 1023-30.

16. Robbins JW. Tissue management in restorative dentistry. Funct Esthet Restor Dent. 2007;1:40-3.

17. Douglas-de-Oliveira DW, Maravilha MNP, Anjos TN, Gonçalves PF, Flecha OD, Tavano K. Clinical and Radiographic Evaluation of the Periodontium with Biologic Width Invasion by Overextending Restoration Margins - A Pilot Study. J Int Acad Periodontol. 2015;17(4):116-22.

18. Parashis AO, Polychronopoulou A, Tsiklakis K, Tatakis DN. Enamel matrix derivative in intrabony defects: prognostic parameters of clinical and radiographic treatment outcomes. J Periodontol. 2012;83(11):1346-52.

19. Ingber JS, Rose LF, Coslet JG. The "biologicwidth" - a concept in periodonticsandrestorativedentistry. Alpha Omegan. 1977;70:62-5.

20. Savadi A, Rangarajan V, Savadi RC, Satheesh P. Biologic Perspectives in Restorative Treatment. J Indian Prosthodont Soc. 2011;11(3):143-8.

21. Sanavi F, Weisgold AS, Rose LF. Biologic width and its relation to periodontal biotypes. J Esthet Dent. 1998;10(3):157-63.

22. Parma-Benfenati S, Fugazzotto PA, Ferreira PM, Ruben MP, Kramer GM. The effect of restorative margins on the postsurgical development and nature of the periodontium. Part II. Anatomical considerations. Int J Periodontics Restorative Dent. 1986;6:64-75.

23. Stetler KJ, Bissada NF. Significance of the width of keratinized gingiva on the periodontal status of teeth with submarginal restorations. J Periodontol. 1987:58(10):696-700
24. Poddar S, Bagchi S, De A, Rambabu D, Savan SR, Chowdhury M. Clinical Significance of Biologic Width in Perio-Restorative Dentistry: A Review. J Adv Med Dental Sci Res. 2018;6(8):82-4.

25. Pimentel JO, Filho AMM, Mota OML, Pereira SLS, Lima DLF, Carlos MX Comparative study between radiographic and surgical evaluation in the diagnosis of invasion of periodontal biological space. Revista de Periodontia. 2006;1:11-5.

26. Prabhu N, Issrani $R$, Mathur S, Mishra G. An innovative radiographic technique for the determination of dimensions of dentogingival unit in North Indian population. J Interdisciplinary Dent. 2016;6(3):135.

27. Jepsen S, Caton JG, Albandar JM, Bissada NF, Bouchard P, Cortellini P, et al Periodontal manifestations of systemic diseases and developmental and acquired conditions: Consensus report of workgroup 3 of the 2017 World Workshop on the Classification of Periodontal and Peri-Implant Diseases and Conditions. J Periodontol. 2018:89(S1):S237-48.

28. Ercoli C, Caton JG. Dental prostheses and tooth-related factors. J Periodontol. 2018:89(S1):S223-36.

\section{Publisher's Note}

Springer Nature remains neutral with regard to jurisdictional claims in published maps and institutional affiliations.
Ready to submit your research? Choose BMC and benefit from:

- fast, convenient online submission

- thorough peer review by experienced researchers in your field

- rapid publication on acceptance

- support for research data, including large and complex data types

- gold Open Access which fosters wider collaboration and increased citations

- maximum visibility for your research: over $100 \mathrm{M}$ website views per year

At $\mathrm{BMC}$, research is always in progress.

Learn more biomedcentral.com/submissions 